\title{
Assessing the Impact of Skilled Labor on Output Growth in South Africa: An ARDL Bound Testing
} Approach

\author{
${ }^{1}$ Tochukwu Timothy Okoli, ${ }^{2}$ Devi Datt Tewari, ${ }^{3}$ Eneh George N. O. \\ 1Department of Economics, University of Zululand, South Africa \\ ${ }^{2}$ Faculty of Commerce, Administration and Law University of Zululand, South Africa \\ ${ }^{3}$ Enugu State Collage of Education (Technical), Nigeria \\ tochukwu.okoli@fuoye.edu.ng,TewariD@unizulu.ac.za, enehgeorgendidi@gmail.com
}

\begin{abstract}
Economic theory emphasized the necessity of skill acquisition and conservation as a precondition for growth. This paper investigates the extent to which skilled labor can contribute to output growth in South Africa in the long run. The theoretical framework employed was based on Hicks neutral augmented CobbDouglas production function to account for the impact of technological progress on labor and capital. Skilled labor was measured with three parameters of experience (learning-by-doing), special training and educational attainments. The methodology employed the ARDL bound testing approach and found that whereas there is no short run causality running from the independent variables to the dependent variable, there was a long run causality running from the measures of skilled labor to growth. The coefficient of the ECT was both significant and negative; therefore, the system gets adjusted towards their long run equilibrium steady state at the speed of 23 percent annually. This means that the measures of skilled labor contribute to growth in the long run to the tune of 23 percent annually. The study therefore recommends investments in human capital through education and special trainings as well as to encourage knowledge transfer through globalization and from one generation to another to conserve skills.
\end{abstract}

Keywords: Autoregressive distributed lag, Bound testing, Growth, Skilled-labor, South Africa

\section{Introduction}

In the recent past, quality attention has been shifted from the use of physical addition of factors of productions in generating growth to the quality of these factors. Evidence abounds both from empirical studies and experience that affirms this assertion. With the global society moving towards a technologically driven economy and policy makers seeking a growth sustainable measure, this research work want to ascertain how the quality of factors of production with emphasis on labor can promote output growth both in quantity and quality. The growth pattern of most emerging economies like South Africa has gone beyond physical input driven to the role of knowledge-based economy with emphasis on the role of human capital especially as a number of studies and surveys have confirmed that the skills shortage is a real problem in South Africa, and a constraint to economic growth. A study done by the Bureau for Economic research (BER) at the University of Stellenbosch found that $47 \%$ of SA manufactures said that the skills shortage was their most serious difficulty. South Africa which is one of the global community that is struggling for resources, especially human resources have not only sourced for human resources abroad but also have being considered not matching the trend of changes in human capital/skilled labor development and as such can be left out in the nearest future in terms of growth if nothing is done about it. Higher education has an important role to play in bridging the skill shortage gap in South Africa by developing qualified graduates and postgraduates through generation of research and innovation (Fisher and Scott, 2011). Again, the primary focus of higher education has been directed towards the development of human capital which can in turn contribute to the economic and socio-political growth of the country (Tewari, 2016). This implies that developing human capital is capable of pivoting the economy to greatness as well as being a means for sustainable growth. The extent to which this can be achieved could be said to depend greatly on the rate and quality of graduates and postgraduates' turnout in different disciplines such as in law, education, sciences and management sciences whereas much has not been recorded in engineering and some basic sciences, hence, the gap in human capital still remains. Moreover, in South Africa, there has been an increasing mismatch between the courses offered and the available jobs. There is therefore the need for higher education institutions not just turning out huge numbers of graduates but graduates whose skills are needed for the furtherance of innovative and profitable economic activities to firms and businesses and other functions of the society (Tewari, 2016). 
With the large budgetary allocation by South African government to higher education, it should be expected that South Africa, unlike other less economically developed countries in Africa should fast catch up with the western counterparts. However, the story seems to be worse as there still remained a large skill requirement gap in the country, thereby creating a form of vicious circle of poverty. This study will therefore proffer the way out of this poverty trap in South Africa by formulating a policy measure through which people can access higher education so as to improve their earning ability as well as suggest ways of maximizing the huge government expenditure on education to permeate the economy and bring about the required development. This study adopts three measures to capture skilled labor which are total number of employment in the tertiary sector of the economy, labor experience and government expenditure on education. The theoretical framework on which the analysis is based is on Cobb-Douglas production function using time series data spanning from 1980 to 2016. This paper is organized in five sections. The first is the introduction path which presents the general overview of the topic followed by the theoretical and empirical reviews so as to drive home the growth determining factors with peculiar reference to South Africa. The third section is the methodology used to estimate the casual relationship between output and its explanatory variables. The empirical results are presented in section four and finally, the conclusions, recommendation and policy implication.

\section{Literature Review}

A number of studies have looked at the relationships between human capital and economic growth. But no study to the best of my knowledge have considered the skill side of human capital; however, most work believed that effective labor is a better concept to measure the quality of human capital, however this concept could not capture the experiences gathered over time. In the work of Idris and Rahmah (2010) where they used effective labor and the level of education as indicators to measure quality of labor and found that capital stock and capital-labor ratio played a major role in contributing to the Malaysian economic growth and labor productivity respectively. Again, the work of Wilson \& Briscoe (2004) which used education and training as proxy for human capital concludes that the overall impact of investment in education and training on national economic growth is positive and significant; Khalafalla \& Suliman (2013) used a simultaneous equation model that links human capital to economic growth, total productivity, foreign direct investment, and human development index in Sudan for the period 1982-2009 and found that the quality of the education has a determinant role in the economic growth; health quality factor has a positive impact on economic growth but total factor productivity has adverse effect on economic growth and human development.

Although a review of literature on the relationship between economic growth and education reveals an ambiguous conclusion. According to the World Bank report, many studies have found that additional years of education per person in the labor force will increase real output or economic growth (World Bank, 1991; 1993), others asserts that human capital accumulation has had a significant negative or an insignificant impact on the growth rate of output. Bloom et al. (2005) believed that education has become a key instrument for the promotion and sustenance of economic growth in many countries. (Gyimah-Brempong et al., 2006) asserts that this is of peculiar importance to South African economy as a middle income economy owing to the excess attention given to growth and growth potentials as a mechanism for poverty and inequality reduction, hence they proposed improvement in the education sector as a policy measure for development and convergence with already developed nations of the world. The World Development Report (1997) examines how knowledge influences development. It observes that the acquisition of knowledge and information is becoming increasingly critical to economic growth and emphasizes that the value of knowledge gained through trade and foreign investment can significantly impact on growth. The report further looks at the role of knowledge in development, examining difference in knowledge across and within the countries, the impact of knowledge gaps and information failures on development, and the way in which governments in developing countries and international institutions can foster development by addressing these issues. This further buttressed the importance of skills acquired through knowledge to output growth. By implication, knowledge across globe can have an impacting influence on another country through technological transfer.

Theoretical Framework: The theoretical framework was based on the neoclassical technological progress labor-augmenting growth model of Harrod thus: 


$$
Q_{t}=A_{t} f\left(K_{t}, L_{t}\right)
$$

Where $\mathrm{Q}$ is output level, $\mathrm{A}$ is technological progress, $\mathrm{K}$ is the physical capital, $\mathrm{L}$ is number of people in employment (Labor), $f$ is a functional notation while $t$ is time. Barro and Sala-i-Martin (1995), show that technological progress can always be expressed as labor-augmenting and proved it mathematically that only labor-augmenting technological change is consistent with the existence of a steady state thus:

$$
Q_{t}=K_{t}^{\alpha}\left(A_{t} L_{t}\right)^{\beta}
$$

From equation (3.2) above $\alpha+\beta=1$ constant returns to scale; $\alpha$ is the output elasticity of capital and $\beta$ is the output elasticity of labor. Barro and Sala-i-Martain (1995) believed that output elasticity of each capital is inversely related to the level of its marginal product. This implies that MP of each factor will be very large as long as the elasticity value becomes very small. However, in this context, South Africa have sufficient amount of technological progress both in capital and labor. Therefore, the Hicks-neutral capital and labor technology augmenting Cobb-Douglas production function in equation (3.1) will be adopted with some modifications.

All the parameters are as defined above. The function only looked at the physical quantity of labor and not the quality or skills acquired by labor; hence it assumes that labor is homogenous, but in actual seen, labor is heterogeneous. This will be accounted for with different measures. By introducing Lucas (1988) and (Idris and Rahmah, 2010) production functions, I can take into account the skills of labor thus:

Where:

$$
Q_{t}=A_{t} K_{t}^{\alpha}\left(L_{t}^{* \beta}\right) .
$$

$$
\mathrm{Lt}^{*}=\mathrm{Let} \mathrm{Lut}_{\mathrm{Ltt}} \mathrm{Lst} \quad \text { is defined as skilled labor.. }
$$

Substituting equation 3.4 into equation 3.3, we derive:

$$
Y_{t}=A_{t} K_{t}^{\alpha}\left(\mathrm{Let}_{\mathrm{Lut}} \mathrm{L}_{\mathrm{tt}} \mathrm{L}_{\mathrm{st}}\right)^{\beta}
$$

Where:

$\mathrm{Y}_{\mathrm{t}}$ is the real output in time $\mathrm{t}$; $A_{\mathrm{t}}$ is the technological progress in time $t$ which is measured by the net flow of Foreign Direct Investment (FDI); $\mathrm{K}_{\mathrm{t}}$ is physical capital stock in time $\mathrm{t}$; Let is the level of education attained by a particular labor in time $t$; $L_{u t}$ is the output level gained through the experience of workers. There has not being a consensus by economists on this but (Idris and Rahmah, 2010) suggested that it is commonly substituted by previous year output level, $\mathrm{Y}_{\mathrm{t}-1}$; Ltt is the training a worker has received which is measured by the amount of government expenditure on education; and $\mathrm{L}_{\text {st }}$ is the total stock of human capital (Labor Force). Furthermore, neoclassical economists believe that output growth rate is directly related to the level of growth of capital and human capital. This means that the growth rate of income is a direct function of the growth rate of capital and labor.

Lucas, (1988) and Romer, (1989) observed that the growth rate of output exceeds the relevant input measures. This implies that there could be other endogenous factors that affect growth which cannot be directly captured by the physical addition of labor and capital. The extended neoclassical growth model adopts an endogenous growth concept by introducing effective labor as factor of production, where human capital is embodied in this measure. This model suggests that endogenously accumulated human capital has a direct impact on the productivity of labor, while the exogenous growth model regards human capital as given and it is not determined within the system (Idris and Rahmah, 2010). Skilled labor as used in this contest is somewhat different from the physical quantity of labor (total employment) as well as effective labor which looks at the values added per worker i.e. the marginal product of labor. It looks at the training, educational attainment and experiences acquired by labor over time which helps to improve his level and quality of output. However, by adopting the concept of skilled labor in this work, my interest goes beyond the effective use of labor to the quality of output produced per worker. My argument being that a worker can be effective in a non-important aspect of production, thereby not being able to produce the desired result since effectiveness is mostly attained through education, however, skill is an experience phenomenon accumulated overtime. Therefore, there is more that experience can add to output than only training can.

\section{Methodology}

Based on the growth model specified under the theoretical framework above, this study employs the Autoregressive Distributed Lag (ARDL) Model bounds testing approach developed by Pesaran et al. (2001) to test whether there is a long run and short run relationship between the measures skilled labor and output 
growth in South Africa. Given that experience has shown that labor and capital are technologically augmenting, moreover Barro and Sala-i-Martain (1995) believed that output elasticity of each capital is inversely related to the level of its marginal product hence; with South Africa have sufficient amount of technological progress both in capital and labor, we therefore specify a Hicks-neutral capital and labor technology augmenting output function thus:

\section{Model Specification}

The econometric form of equation (3.5)

$\mathrm{Y}_{\mathrm{t}}=\beta_{0}+\beta_{1} A_{t}+\beta_{2} K_{t}+\beta_{3} \mathrm{Le}_{\mathrm{t}}+\beta_{4} \log (\mathrm{Lt})_{t}+\beta_{5} \mathrm{Lu} \mathrm{t}-1+\beta_{6} L S t+\mu_{t}$

Where:

\begin{tabular}{|c|c|c|c|}
\hline $\mathrm{Y}_{\mathrm{t}}$ & $R G D P_{t}$ & $=$ & Real Gross Domestic Product in the current period \\
\hline$A_{t}$ & $\begin{array}{l}=\quad \text { Fdit } \\
\text { the current period }\end{array}$ & & Foreign Direct Investment, proxy for technological progress in \\
\hline$K$ & $\begin{array}{l}=\quad I N V_{t} \\
\text { capital/investmen }\end{array}$ & $\begin{array}{l}= \\
\text { nt ir }\end{array}$ & $\begin{array}{l}\text { Gross Capital Formation as a ratio of GDP, measure for } \\
\text { current period }\end{array}$ \\
\hline
\end{tabular}

Le $=\quad$ Emptst $=\quad$ Employment in tertiary sector, a proxy for skilled labor (labour's level of educational attainment) in the current period.

$\mathrm{Lt}_{t}=\log (G x e)_{t}=\log$ of Government Expenditure in Education, a proxy for training received

$\mathrm{L}_{\mathrm{t}-1}=\quad$ Gdpgrt $_{\mathrm{t}-1}=\quad$ Gdp growth rate, a proxy for experience in production

Lst $\quad=\quad$ Lforce $_{t}=$ Total labor force in the current period

The unrestricted error correction term (the residuals) obtained from equation (3.6) constitutes all other unexplained factors that impacts on output growth in South Africa, such as socio-cultural and economic factors that promotes or inhibits growth is used to form the ARDL representation of the skill labor and economic growth relationship, but before that, the long run co-integration test will be conducted with the use of equation (3.7):

$$
\begin{aligned}
& \Delta G D P G R_{t}=\delta_{o}+\delta_{1} G D P G R_{t-1}+\delta_{2} F D I_{t-1}+\delta_{3} I N V_{t-1}+\delta_{4} E_{M P P S}+\delta_{t-1} L O G(G X E)_{t-1} \\
& +\delta_{6} G_{P P P C}+\delta_{7-1} L F O R C E+\sum_{i-1}^{k} \beta_{i} \Delta G D P G R_{t-i}+\sum_{i-1}^{k} \beta_{i} \Delta F D I_{t-i}+\sum_{i-1}^{k} \beta_{i} \Delta I N V_{t-i}+\sum_{i-1}^{k} \beta_{i} \Delta E M P T S_{t-i} \\
& +\sum_{i=1}^{k} \beta_{i} \Delta L O G(G X E)_{t-i}+\sum_{i-1}^{k} \beta_{i} \Delta G D P P C_{t-i}+\sum_{i-1}^{k} \beta_{i} \Delta L F O R C E_{t-i}+\mu_{t}
\end{aligned}
$$

In the above model, $\Delta$ is the first-difference operator; $\mathrm{k}$ is the ARDL model maximum lag order and chosen by the researcher; while all $\beta_{\mathrm{i}}$ 's represent the short-run dynamics of the model, whereas the long run dynamics will be tested with the use of the ECT as will be specified in equation (3.10) below. The long run coefficient must be negative and at the same time significant before we can conclude that the variables converges in the long run, that is, their short run errors will be corrected in the long run. The non-existence of the long-run relationship is defined by;

$H_{0}: \delta_{1}=\delta_{2}=\delta_{3}=\delta_{4}=\delta_{5}=\delta_{6}=0$ (null, i.e. the long run relationship does not exist).

$H_{1}: \delta_{1} \neq \delta_{2} \neq \delta_{3} \neq \delta_{4} \neq \delta_{5} \neq \delta_{6} \neq 0$ (Alternative, i.e. the long run relationship exists) 
The hypothesis is tested by means of the F-statistic (Wald test) in equation (3.8) and (3.9), respectively. The F-calculated is tested against the critical values of the F- statistics which has two sets of values.

Granger (1988) is of the view that causal relationship among variables can be examined within the framework of ECT, with co-integrated variables. That is, to establish a long-run relationship among the variables, the coefficient of the ECT ( $\lambda$ ) from the specified ARDL model in equation (3.10) should exhibit a negative and significant sign for causality to exist in the long run. If that is the case, it implies that in the long run, output growth will revert to its mean hence; the effect of those unexplained variables will diminish overtime. While the short run dynamics are captured by the individual coefficients of the lagged differenced terms, $\lambda$ the error correction term (ECT) contains the information of long run causality.

$$
\begin{aligned}
& \Delta R G D P_{t}=\delta_{o}+\sum_{i=1}^{k} \beta_{i} \Delta R G D P_{t-i}+\sum_{i=1}^{k} \beta_{i} \Delta F D I_{t-i}+\sum_{i=1}^{k} \beta_{i} \Delta I N V_{t-i}+\sum_{i-1}^{k} \beta_{i} \Delta E M P T S_{t-i}+\sum_{i-1}^{k} \beta_{i} \Delta L O G(G X E)_{t-i}+ \\
& \sum_{i=1}^{k} \beta_{i} \Delta G D P G R_{t-i}+\sum_{i=1}^{k} \beta_{i} \Delta L F O R C E_{t-i}+\lambda E C T_{t-1}+\mu_{t}
\end{aligned}
$$

In order to test for the parameter stability, we employed Pesaran and Pesaran (1997) parameter stability test. Pesaran and Pesaran (1997) suggested that once the error correction models have been estimated, the parameter stability test will be estimated by applying the cumulative sum of recursive residuals (CUSUM) and the CUSUM of square (CUSUMSQ) tests to assess the parameter constancy.

Data Source and Justification: The study used a time series secondary data spanning from 1980 to 2016, a data set of thirty-seven years. This is considered long enough to accommodate both the colonial/apartheid and post-colonial effects on skilled labor acquisition and how it has impacted on output growth. Moreover, the data set is also necessary as to generate sufficient changes overtime in the education sector that is capable of improving output. The data was gathered both from the World Bank database and the South African Reserve Bank statistical bulletins.

\section{Results and Discussion}

The empirical results from this study starts with the unit root test which we conducted using the Augmented Dicky-Fuller and Philip-Perron stationarity tests. As one of the preliminary tests that should be conducted to certify whether an ARDL model is preferable or not in that the series must be a combination of I(1) and I(0), as well as that the unit root test for the error term from equation (3.6) must be of order zero (ie I(0)) suggestive of the adoption of the ARDL bound testing model. Next is the lag length selection criterion and then to the co-integration test to see whether the variables move together in the long run. This will lead us to the bound testing error correction estimation; followed by the Wald-coefficient diagnostic test and finally the stability tests.

Unit Root Test: This we can do with the use of the Augmented Dickey and Fuller (1979) and Phillips and Perron (1988) Unit root tests as it remains the better tests for stationarity.

Table 1: Unit Root Test: ADF and PP Tests

\begin{tabular}{lllllllll}
\hline \multirow{2}{*}{ DATAS } & INTERCEPT & TREND & \multicolumn{2}{c}{ ADF TEST } \\
ORDER & $\begin{array}{l}\text { VALUE OF } \\
\text { ADF TEST }\end{array}$ & $\begin{array}{l}\text { P- } \\
\text { VALUE }\end{array}$ & PP TEST \\
ORDER & & $\begin{array}{l}\text { VALUE OF } \\
\text { PP TEST }\end{array}$ & P-VALUE \\
\hline Empts & YES & NO & I(1) & -5.175676 & 0.0002 & $\mathrm{I}(1)$ & -5.280954 & 0.0001 \\
Inv & Yes & Yes & I(1) & -7.761701 & 0.0000 & $\mathrm{I}(1)$ & -7.707069 & 0.0000 \\
GDPPC & Yes & Yes & $\mathrm{I}(1)$ & -4.202787 & 0.0110 & $\mathrm{I}(1)$ & -4.280030 & 0.0091 \\
GDPgr & Yes & Yes & $\mathrm{I}(0)$ & -4.395575 & 0.0067 & $\mathrm{I}(0)$ & -4.393654 & 0.0067 \\
Log(GXE) & No & No & $\mathrm{I}(1)$ & -4.814231 & 0.0025 & $\mathrm{I}(1)$ & -2.787761 & 0.0067 \\
LForce & Yes & Yes & $\mathrm{I}(1)$ & -4.198364 & 0.0112 & $\mathrm{I}(1)$ & -4.198364 & 0.0112 \\
FDI & Yes & Yes & $\mathrm{I}(0)$ & -4.790096 & 0.0024 & $\mathrm{I}(0)$ & -4.619719 & 0.0038 \\
ECT & Yes & Yes & $\mathrm{I}(0)$ & -3.011826 & 0.0438 & $\mathrm{I}(0)$ & -2.963313 & 0.0487 \\
\hline
\end{tabular}

Source: Estimation 
From the result of the Augmented Dickey Fuller and Philips Perron Unit Root Tests in the table above, we could deduce that the variables revealed different levels of integration, that is I(0) and I(1), moreover, it is important to note here that another necessary condition to estimate the ARDL bound testing approach is that the Error Correction Term (ECT) derived from the OLS estimate of equation (3.6) must be stationary at level. This condition is also fulfilled. As the ECT Unit Root test was stationary with both the ADF and PP Stationarity tests. Therefore, the Autoregressive Distributed Lag Model (ARDL $(1,1)$ ) to bound testing approach of equation (3.10) will be used to ascertain their long run as well their short run dynamics. The results as presented in the Table 1 above revealed that both tests results are consistent to each other and that all our data are I(1) and I(0), so we can proceed to test for the lag. Lag length test is conducted by estimating single equation VAR and using the lag length criteria to obtain the optimal number of lags for the variable. The result is presented in Table 2 below thus:

Table 2: Lag Length Selection VAR Lag Order Selection Criteria Included observations: 31

\begin{tabular}{ccccccc}
\hline \hline Lag & LogL & LR & FPE & AIC & SC & HQ \\
\hline \hline 0 & -727.6693 & NA & $2.27 e+19$ & 47.39802 & 47.72182 & 47.50357 \\
1 & -703.0548 & $36.52471^{*}$ & $4.96 e+18^{*}$ & $45.87450^{*}$ & $46.24456^{\star}$ & $45.99513^{\star}$ \\
2 & -702.9714 & 0.118289 & $5.29 e+18$ & 45.93364 & 46.34996 & 46.06935 \\
3 & -702.9713 & 0.000160 & $5.68 e+18$ & 45.99815 & 46.46073 & 46.14894 \\
\hline \hline
\end{tabular}

* indicates lag order selected by the criterion

LR: sequential modified LR test statistic (each test at $5 \%$ level)

Source: Estimation

The different lag order selection information criterions used are Final Prediction Error (FPE), Akaike Information Criterion (AIC), Schwarz Information Criterion (SIC) and Hannan-Quinn Information Criterion (HQ). All the variables were grouped in a VAR equation and tested to ascertain the number of lags required to run the ARDL model. The result as presented in table 2 suggests that all the lag order selection criteria choose lag one for the model. The researchers then proceed to the ARDL bounds testing approach to co-integration and the result is presented as shown in Table 3 below.

Our variables are co-integrated at 5\% level of significance. The F-statistics value is more than the Upper bound of the critical values at 5\% level of significance. Moreover, the probability value revealed that we should reject the null hypothesis because it is less than $5 \%$. Having ascertained that the variables go together in the long run, we then check their long run causality with the use of the coefficient of the ECT in equation (3.10). The short run dynamics will be tested using the individual $\beta_{i}$ whereas to know if the variables will converge to their long run steady state, will be ascertain with $\lambda$. If the one period lag of ECT is both significant and negative, then the variables will converge to their long run steady state otherwise it will not.

\section{Table 3: Result of ARDL Bounds Test for Co-integration}

\begin{tabular}{|c|c|c|c|}
\hline $\mathrm{F}$ (All variables) & $P-1=7-1=6$ & 5.578364 & 0.0013 \\
\hline Critical Values & Lower BoundI(0) & Upper BoundI(1) & \\
\hline $5 \%$ & 2.476 & 3.646 & \\
\hline $\begin{array}{l}\mathrm{H}_{0}: \mathrm{H}_{0}: \delta_{1}=\delta_{2}=\ldots \delta_{6}=0 \text { (no long run } \\
\text { relationship) }\end{array}$ & & & Reject \\
\hline $\begin{array}{l}\mathrm{H}_{1}: \delta_{1} \neq \delta_{2} \neq \ldots \neq \delta_{6} \neq 0 \text { (long run } \\
\text { relationship exists) }\end{array}$ & & & Accept \\
\hline
\end{tabular}

Source: Estimation

From the result in Table 4 below, we can deduce that the two conditions for a long run state are fulfilled. This is because the coefficient of one period lag of the Error Correction Term (ECT) derived from equation (3.10) is significant at five percent level of significance and at the same time negative, hence, we can say that the speed of adjustment to their long run steady state is at the rate of about $23 \%$ annually. This means that in the 
long run, labor productivity or value added to the overall Real Gross Domestic Product (RGDP) will improve by 23 percent annually. This means that in the long run, skilled labor as well as other explanatory variables will improve total productivity in South Africa to the tune of 23 percent annually through training, adequate and optimal government spending in education and experience of the works over time.

Table 4: The Parsimonious Result of the ECM Bound Testing Result Included observations: 33 after adjustments

\begin{tabular}{crrrr}
\hline \hline Variable & Coefficient & Std. Error & t-Statistic & Prob. \\
\hline \hline C & $2.32 \mathrm{E}+09$ & $2.23 \mathrm{E}+09$ & 1.041982 & 0.3078 \\
$\mathrm{D}($ RGDP(-1)) & 0.526225 & 0.212614 & 2.475024 & 0.0208 \\
D(TECH_FDI_(-1)) & -0.348174 & 0.352131 & -0.988763 & 0.3326 \\
D(INV(-1)) & 15456978 & $5.53 \mathrm{E}+08$ & 0.027940 & 0.9779 \\
D(EMPTS(-1)) & 947.2446 & 6584.226 & 0.143866 & 0.8868 \\
D(LOG(GXE(-1))) & $1.48 \mathrm{E}+10$ & $9.71 \mathrm{E}+09$ & 1.521218 & 0.1413 \\
D(GDPGR(-1)) & $4.28 \mathrm{E}+08$ & $4.29 \mathrm{E}+08$ & 0.997166 & 0.3286 \\
D(LFORCE(-1)) & -2740.879 & 3148.770 & -0.870460 & 0.3927 \\
ECT(-1) & -0.234566 & 0.111382 & -2.105967 & 0.0459 \\
\hline \hline
\end{tabular}

Source: Estimation

However, in order to check whether labor can impact on output in the short run, the wald-coefficient test will be conducted on the short run variables as presented on the table below:

Table 5: Wald Coefficient Diagnostic Test for Short Run Dynamics

\begin{tabular}{|c|c|c|c|c|c|}
\hline Selected Coefficient & $\begin{array}{ll}\text { Short } & \text { run } \\
\text { Variables } & \\
\end{array}$ & $\begin{array}{l}\text { Test } \\
\text { Statistics }\end{array}$ & $\begin{array}{l}\text { P- } \\
\text { Value }\end{array}$ & Decision & $\begin{array}{l}\text { Interpretation/ } \\
\text { Conclusion }\end{array}$ \\
\hline $\begin{array}{l}\mathrm{H}_{0}: \mathrm{C}(5)=\mathrm{C}(6)= \\
\mathrm{C}(7)=\mathrm{C}(8)=0 \\
\mathrm{H}_{1}: \mathrm{C}(5) \neq \mathrm{C}(6) \neq \\
\mathrm{C}(7) \neq \mathrm{C}(8) \neq 0\end{array}$ & $\begin{array}{l}\text { Combined effect } \\
\text { of lags of all Labor } \\
\text { Components }\end{array}$ & $\begin{array}{l}\text { Chi-square } \\
0.818091\end{array}$ & 0.5263 & $\begin{array}{l}\text { Accept null } \\
\text { Hypothesis }\end{array}$ & $\begin{array}{l}\text { All the lagged labor } \\
\text { variables cannot } \\
\text { impact Growth in } \\
\text { the short run }\end{array}$ \\
\hline $\begin{array}{l}\mathrm{H}_{0}: C(2)=\mathrm{C}(3)=\mathrm{C}(4)=0 \\
\mathrm{H}_{1}: \mathrm{C}(2)=\mathrm{C}(3) \neq \mathrm{C}(4) \neq 0\end{array}$ & $\begin{array}{l}\text { Combined effect } \\
\text { of other } \\
\text { determinants of } \\
\text { growth (FDI, INV, } \\
\text { etc) }\end{array}$ & $\begin{array}{l}\text { Chi-square } \\
7.485566\end{array}$ & 0.0841 & $\begin{array}{l}\text { Accept null } \\
\text { Hypothesis }\end{array}$ & $\begin{array}{l}\text { All the lags of } \\
\text { investment, FDI } \\
\text { output variables } \\
\text { cannot impact } \\
\text { Growth in the short } \\
\text { run }\end{array}$ \\
\hline
\end{tabular}

Source: Estimation

The short run result table above shows that all the explanatory variables do not impact on the dependent variable in the short run; this means that the different aspects of labor skills that an individual can acquire will not have an outstanding effect on the growth rate of output in South Africa in the short run because the lagged coefficients tests on them which was conducted reveals that we have to accept the null hypothesis that their combined effect is zero. This seems to be consistent with reality and economic theories in the sense that the value labor adds to output due to his/her technical knowhow, educational attainments, trainings received and experiences cannot be measured immediately but has a long run permeating effect on virtually all the sectors of the economy. Also, technological progress which is measured by Foreign Direct Investment (FDI) flows does not have a short run effect because the F-statistics of the wald-coefficient test for it was not significant. It also means that technological progress will be a long run policy issue in South Africa.

Stability Test: Finally, we will examine the stability of the long-run and short run parameters used in our model to test whether the residuals are stable or not, that is, to check if the residuals persistently stray outside the error bounds -2 and +2 or not. This test will be conducted using two different test procedures as 
proposed by Borensztein et al (1998). They are the cumulative sum (CUSUM) and cumulative sum squares (CUSUMSQ) tests. Many researchers prefer these tests in testing for the long-run coefficients' stability. They include Santos (2014), Pesaran and Pesaran (1997), Mohsen et al. (2002). The tests are applied to the residuals of the ECM model stated above.

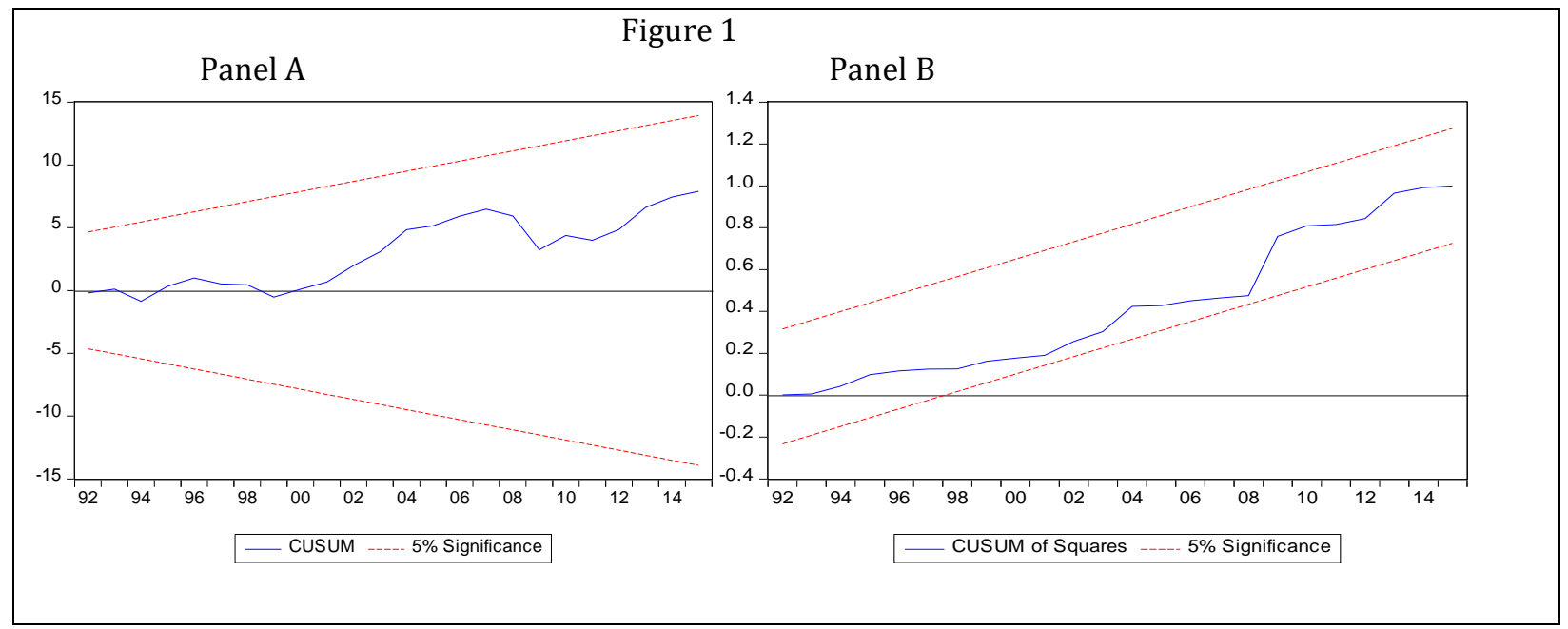

Source: Estimation

The result of the stability test shown in Figure 1 above indicates that the model passes the stability test therefore we cannot reject the null hypothesis; both tests in panel A and B reveal that the estimate and the variance were stable since the residuals and the squared residuals fell within the 5 percent critical boundaries. Since the plots of CUSUM and the CUSUM SQUARES stay within the critical $5 \%$ bounds that confirms the long-run relationships among variables and thus shows the stability of coefficient in equation (3.4).

Result of Diagnostic Test for the Aggregate Growth Model: The diagnostic tests of Serial Correlation, Heteroscedasticity and Normality test was conducted for the ARDL Bound testing model to examine its reliability for policy measures as shown in table7 below. From the table we fail to reject the null hypothesis of residuals being normally distributed since the p-value $(0.269504)$ of the Jarque Bera test statistics is greater than 5 percent. The probability value of the LM Version (0.0577) and F Version $(0.2628)$ of the BreuschGodfrey Serial Correlation LM test shows that there is no presence of serial correlation in the model; therefore, we fail to reject the null hypothesis of there is no serial correlation in the model. The study also found no presence of heteroscedasticity, this is because the p-value of both the LM test (0.7683) and the FVersion (0.7771) is statistically significant at the 5 percent level (See Table 7).

Table 6: Result of Diagnostic Tests for the Aggregate Growth Model

\begin{tabular}{|c|c|c|c|c|c|}
\hline Test Statistics & Hypotheses & LM Version & P-Value & F Version & P-Value \\
\hline Normality & $\begin{array}{l}\mathrm{H}_{0}: \text { Residuals are } \\
\text { normally } \\
\text { distributed }\end{array}$ & $\mathrm{JB}=2.69504$ & 0.269504 & Not Applicable & $\begin{array}{l}\text { Not } \\
\text { Applicabl } \\
\text { e }\end{array}$ \\
\hline Serial Correlation & $\begin{array}{l}\mathrm{H}_{0}: \text { There is no } \\
\text { Serial Correlation }\end{array}$ & $\begin{array}{l}\text { Chi-Square(1) = } \\
1.464049\end{array}$ & 0.2263 & $\begin{array}{l}\mathrm{F}(1, \quad 23) \\
1.067770\end{array}$ & 0.3122 \\
\hline Heteroscedasticity & $\begin{array}{l}\mathrm{H}_{0}: \text { There no is } \\
\text { Heteroscedasticity }\end{array}$ & $\begin{array}{l}\text { Chi-Square(1) }= \\
0.086810\end{array}$ & 0.7683 & $\begin{array}{l}\mathrm{F}(1, \quad 30) \\
0.081606\end{array}$ & 0.7771 \\
\hline \multicolumn{6}{|c|}{$\begin{array}{l}\text { Normality - Jarque-Bera Test Statistics } \\
\text { Breusch-Godfrey Serial Correlation LM Test } \\
\text { Heteroscedasticity Test: ARCH Effect }\end{array}$} \\
\hline
\end{tabular}




\section{Conclusion and Policy Recommendations}

This study investigates the impact of skilled labor on the output growth of South Africa for the period 19802016. The choice of the period was basically due to the non-availability of data for the periods before that. The theoretical framework employed adopted the Hicks neutral augmented Cobb-Douglas production function and measured labor skills with three parameters of experience (learning-by-doing), special training and educational attainments. The methodology applied was the ARDL bound testing approach for the long run and short run dynamics of our model given that the series are I(1) and I(0). Augmented Dickey-Fuller (ADF) and Philips Perron tests for stationarity were used to ascertain whether the variables have Unit root. Furthermore, ARDL test for co-integrations using the Wald- coefficient test revealed that all the variables move together in the long run. Also the result of the ARDL model revealed that whereas there is no short run causality running from the independent variables to the dependent variable, the system gets adjusted towards their long run equilibrium steady state at the speed of 23 percent annually. This means that it takes the system about five years into the long run to start experiencing the positive impact of skilled labor in economic growth rate of South Africa. To be more specific, assuming that there where hundred law graduates, economists, chartered accountants, etc. their contributions to growth will have a significant effect after five years. Skilled labor which is measured with three proxies of government expenditure on education, workers' experience with the lag of output in the previous period and employment in tertiary sector does not impact significantly on output growth in the short run, however, all of them jointly impacts on output growth in the long run. This is consistent with the findings Khalafalla \& Suliman (2013) who affirms that the quality labor impacts significantly with economic growth in Sudan.

On the other hand, the findings of this work affirms that among emerging nations like South Africa, output growth is still heavily dependent on the level of physical quantity of labor rather than on the quality of labor as well as other inputs. This is because the proxies for the quality of labor could not account for growth in South Africa in the short run, however, output in the previous period does. This is consistent with the findings of Idris and Rahmah (2010) in Malaysia who observed that although effective labor did play a positive role in determining economic growth but its contribution is less than the physical labor, thereby confirming the assertion that physical quantity of labor impacts more on output than its quality. Also from the result of the findings, it can be established that one of the ways out of the poverty trap or vicious circle of poverty is by the improvement of human skill through training, increased government expenditure on education especially on the vocational and technical aspects. This is because better skill acquisition will attract higher and better earnings and at the same time promote self-dependency, job satisfaction, on the job training as well as make for skill sustainability in the long run. Therefore, policy makers should concentrate efforts in ensuring that budgetary allocation towards education trickles down. Moreover, for the fact that in the short run, skilled labor could not significantly impact on education could be as a result of excess bureaucracy and misappropriation of fund within the system. This also should be checked.

The long run causality was tested with the ECT in equation (3.10) which was error term derived from regressing the independent variables on the growth of output in equation (3.6). It showed that there is a long run convergence of the whole system to their long run steady state growth path because the coefficient of ECT was both negative and significant at 5 percent level of significance. This implies that all the explanatory variables such as labor experience, labor training and education as well as capital formation and technological progress in the economy is a long run phenomenon and as such, policies to improve labor productivity should be geared towards the long run and not short run. Also, all the unexplained factors that impacts on output growth in South Africa such as the socio-cultural and economic variables/factors has been accounted for under the error term and as such their effects on output growth will diminish in the long run. Moreover, there was no short run causality running among the variables, hence, we can deduce that contributions or impact of skilled labor to growth should be expected in the long run only. Finally, the stability of the model was conducted using the CUSUM and CUSUMSQ and it revealed that the residuals are stable; hence there is no possibility of skilled labor not having the expected impact due to possible outliers that disturbs the system. This was checked using the diagnostic tests and evidence shows that there was absence of heteroscedasticity, the error was normally distributed and there was serial correlation in the model. Therefore, South Africa should pursue labor efficiency policies more diligently in the long run and at the same manner encourage the 
transfer of skills from the skilled foreigners to the citizens as this will have a long run implication for the economy.

\section{References}

Barro R. \& Sala-i-Martin, X. (1995). Economic Growth. McGraw-Hill, New York.

Becker, G. S. (1964). Human capital: A Theoretical and Empirical Analysis, with Special Reference to Education. Chicago, University of Chicago Press. ISBN 978-0-226-04120-9.

Bloom, D. E., Canning, D. \& Sevilla, J. (2005). Health and economic growth: reconciling the micro and macro evidence. Center on Democracy, Development and the Rule of Law Working Papers, 42.

Borensztein, E., De Gregorio, J. \& Lee, J. W. (1998). How does FDI affect economic growth? Journal of International Economics, 45(1), 115-135.

Dickey, D. \& Fuller, W. (1979). Distribution of the estimators for autoregressive time series with a unit root. Journal of the American Statistical Association, 74(366), 427-731.

Fisher, G. \& Scott, I. (2011). Background Paper 3: The role of Higher Education in Closing the skills Gap in South Africa. The World Bank, October.

Granger C. W. J. (1988). Causality, cointegration and control. Journal of Economic Dynamics and Control, 12(23), 551-559.

Gyimah-Brempong, K., Paddison, O. \& Mitiku, W. (2006). Higher Education and Economic Growth in Africa. Journal of Department Studies, 42(3), 509-529.

Haug, A. A. (2002). Temporal aggregation and the power of cointegration tests: A monte carlo study. Oxford Bulletin of Economics and Statistics, 64(4), 399-412

Idris, J. \& Rahmah, I. (2010). Impact of labor quality on labor productivity and economic growth. African Journal of Business Management, 4(4), 486-495, April 2010 http://www.academicjournals.org/AJBM ISSN 1993-8233.

Khalafalla \& Suliman. (2013). The Impact of Human Capital on Economic Growth: Empirical Evidence from Sudan. www.sciedu.ca/rwe Research in World Economy, 4(2), 2013.

Lucas, R. E. Jr. (1988). On the mechanics of economic development. J. Monet. Econ., 22, 3-42.

Mohsen, K., Oskooee, B. \& Ng, R. W. (2002). Long run demand for money in Hong Kong: An application of the ARDL model. International Journal of Business and Economics, 1(2), 147-155

Pesaran, M. H. \& Pesaran, B. (1997). Working with Microfit 4.0: interactive econometric analysis; [Windows version]. Oxford University Press.

Pesaran, M. H., Shin, Y. \& Smith, R. J. (2001). Bounds testing approaches to the analysis of level relationships. Journal of Applied Econometrics, 16(3), 289-326.

Romer, P. (1989). Capital accumulation and long-run growth, in R.J. Barro ed. Modern Business Cycle theory, MA Cambridge, MA: Harvard University Press.

Wilson, R. A. \& Briscoe, G. (2004). The impact of human capital on economic growth: a review. http://www.trainingvillage.gr/etv/Projects_Networks/ResearchLab/

Santos Alimi, R. (2014). ARDL bounds testing approach to cointegration: a re-examination of augmented fisher hypothesis in an open Economy. Asian Journal of Economic Modelling, 2(2), 103-114. http://www.aessweb.com/journals/5009

Tewari D. D. (2016). South African Higher Education Sector and its Goals: Reflections and Future Needs. Interdisciplinary Journal of Economics and Business Law, 5(4), 43-78.

World Bank. (1991). World Development Report 1991 Challenges of Development New York Oxford University Press for the World Bank.

World Bank. (1997). Knowledge and development. Bulletin, 8(4), 1-24. 